\title{
Source of harpacticoid copepods in the diet of juvenile starry flounder
}

\author{
J. N. McCalI* \\ Department of Zoology and Physiology, Louisiana State University, Baton Rouge, Louisiana 70803, USA
}

\begin{abstract}
Juvenile (10 to $25 \mathrm{~mm}$ ) starry flounder Platichthys stellatus Pallas feed intertidally in Auke Bay, Alaska, USA, and show high selectivity for the meiobenthic harpacticoid copepod Microarthridion littorale (Poppe). This species is found in high relative abundance in gut contents and males are taken as prey in much greater numbers than females or copepodites. Possible causes of selection were investigated by comparing gut contents with harpacticoid assemblages collected by a variety of techniques. Vertically-sectioned sediment cores give no indication that $M$. littorale differs significantly in vertical distribution from other harpacticoids, suggesting that selective predation does not result from differing availability in the sediment. A series of collections gave no indication that the fish are feeding at other sites on the beach. $M$. littorale is slightly larger than other sediment-dwelling harpacticoids, but there is no significant difference between males and females, implying that selection cannot be entirely attributed to size-selective predation. Analysis of emergence and settlement trap collections point toward differential emergence patterns among potential prey as a possible explanation. Juvenile starry flounder do not feed by biting into the sediment but rather strike at prey objects in the water column. The observed pattern of selection may be a result of emergent behavior of male $M$. littorale. Species and demographic-stage identification proved very important to the interpretation of these data. For example, major taxon level comparisons suggest that harpacticoid densities decline in response to predation pressure. Species-level identifications, however, provide no evidence that harpacticoid densities are limited by predation.
\end{abstract}

\section{INTRODUCTION}

A large body of research has recently highlighted the importance of meiofauna in the diet of a wide variety of juvenile fishes. Gee (1989) and Coull (1990) reviewed literature for meiofauna in general and for harpacticoid copepods, respectively. Although there was a time when the significance of meiofauna as food for juvenile fish was widely debated (see McIntyre 1969), it is now well established that in a number of groups, including flatfish, gobies and selected salmonids, meiofauna play a critical role in the survival and growth of juvenile fish. Many questions remain, however, concerning the modes of utilization of such prey.

While meiofauna consists of a diverse assemblage of organisms, nematodes and harpacticoid copepods

\footnotetext{
- Present address: Division of Natural Science and Mathematics, Livingston University, Livingston, Alabama, USA
}

are normally numerically dominant (Coull 1988). Nematodes are usually much more abundant than harpacticoid copepods, particularly in muddy substrates where they may comprise as much as $97 \%$ of all meiofauna (e.g. Fleeger et al. 1989). This numerical dominance of nematodes, however, is seldom reflected in the diet of meiobenthic predators. Generally, harpacticoid copepods are selectively ingested over all other taxa. This topic is still a matter of some debate (see discussions in Gee 1989 and Coull 1990), but it is apparent that harpacticoid copepods are extremely important food items, often to the complete exclusion of other prey types.

Species-specific selective feeding on harpacticoids has been indicated in a few studies. Sibert (1979) found that Harpacticus uniremis was consumed by salmon fry in British Columbia (Canada) in greater proportions than its abundance in the sediments would predict. This is likely due in part to the fact that $H$. uniremis is largely epiphytic, found predominately on seagrasses. 
Hicks (1984) found that juvenile flatfish feeding on intertidal sandflats in New Zealand fed exclusively on the harpacticoid Parastenhelia megarostrum. This species was dominant in the sediments, but was by no means the only copepod present. Fish and crustacean predators feeding in a sandy habitat in England were highly selective for a particular species of harpacticoid, Asellopsis intermedia, apparently resulting primarily from their surficial distribution in the sediment (Gee 1987). Most locales contain a variety of harpacticoid species, which may differ greatly in size, morphology, behavior and microhabitat utilization (Hicks \& Coull 1983). Given an assortment of potential harpacticoid prey species, it is likely that predator selectivity will prove to be common. Some researchers have taken advantage of this fact to gain insight into feeding behavior of juvenile fish (Feller et al. 1990), but potentially misleading conclusions can result from major taxon level identifications.

A multi-year investigation of feeding in juvenile starry flounder (Platichthys stellatus Pallas) in a southeast Alaskan bay has shown intensive predation on harpacticoid copepods in the intertidal zone (McGregor 1991). This flounder is highly selective for a particular species of harpacticoid, Microarthridion littorale (Poppe). Furthermore, juvenile starry flounder prey much more heavily on male $M$. littorale than on other demographic groups.

Several hypotheses can be advanced to explain the high degree of selection for Microarthridion littorale in general, and males in particular, exhibited by juvenile Platichthys stellatus. These explanations fall into 2 general categories: those which invoke a true selection of prey by the action of the predator and those in which apparent selection is due to an inaccurate assessment of the available prey (the researcher samples in a different fashion from the fish). The purpose of this work is to further characterize the feeding of $P$. stellatus and the nature of the harpacticoid community with the specific goal of determining the source of prey and the factors leading to the apparent high selectivity for particular prey types.

\section{METHODS}

Long-term studies. Juvenile 10 to $25 \mathrm{~mm}$ standard length) Platichthys stellatus were collected approximately every 2 wk from March 1987 through July 1988. The collection site was a beach in Auke Bay, ca $30 \mathrm{~km}$ north of Juneau, Alaska. Auke Bay is a small bay that is relatively shallow for the region $170 \%$ less than $60 \mathrm{~m}$ in depth), with a predominately muddy substrate. Fish were collected in a sheltered cove adjacent to an intertidal mudflat ca $60 \mathrm{~m}$ wide. The beach is characterized by a transition from a Mytilus trossulus zone in the high intertidal, through a barnacle-Fucus zone, to the mudflat which begins just above the mean low water level. There are patches of the seagrass Zostera marina in the area.

Fish were collected at low tide with a $17 \times 2 \mathrm{~m}$ beach seine with $6 \mathrm{~mm}$ stretch mesh, usually between the $0 \mathrm{~m}$ and $-1 \mathrm{~m}$ levels on the beach, in water less than $1 \mathrm{~m}$ in depth. The $0 \mathrm{~m}$ tide level is defined as the mean low water mark. Collections were made in the morning, corresponding to summertime low tides in the region. Flounder were preserved in $10 \%$ buffered formalin. Stomachs were dissected and prey items enumerated and identified to major taxon. Details are discussed in McGregor (1991).

Meiofauna collections were obtained in association with seining and consisted of 4 replicate cores taken with a hand-held piston corer constructed from a $50 \mathrm{~cm}^{3}$ syringe. The upper $5 \mathrm{~cm}$ of sediment and any overlying water were retained. Samples were passed through $500 \mu \mathrm{m}$ and $63 \mu \mathrm{m}$ sieves. Organisms retained on the $63 \mu \mathrm{m}$ sieve were extracted using sucrose flotation, stored in $5 \%$ formalin, stained with rose bengal and identified to major taxon under a stereomicroscope. Results of this work are detailed in McGregor (1991).

These samples, along with flatfish stomach contents, were subsequently transported to our laboratory at Louisiana State University. There, harpacticoid copepods were identified, where possible, to species and demographic group (adult male, adult female, gravid female and copepodite).

Short-term studies. An intensive investigation was carried out during July 1989. During a 2 wk period, approximately 150 juvenile flatfish were collected by seining on 4 occasions, in a similar fashion to those collected during the long-term study.

In addition, an effort was made to more completely describe the harpacticoid community on the beach. This investigation included several components:

(1) Two series of vertically sectioned samples from the $0 \mathrm{~m}$ tide level. These were taken on July 7 and 20 , 1989. The first collection included 4 replicate samples from randomly chosen locations on the $0 \mathrm{~m}$ transect (as in the long-term study), each of which was separated into 6 vertical sections, five $2 \mathrm{~mm}$ thick sections ranging from the surface of the sediment to a depth of $1 \mathrm{~cm}$, and a section from 1 to $2 \mathrm{~cm}$. The core-extruding device was based on that described by Fuller \& Butman (1988). The July 20 collection consisted of 6 replicate samples from the same transect, each of which was sectioned into $2 \mathrm{~mm}$ thick strata to a depth of $1 \mathrm{~cm}$. These samples were part of a larger effort described below. All samples were preserved in $5 \%$ buffered formalin containing Rose Bengal. The sam- 
ples were sorted to major taxon and the harpacticoid copepods were identified to species and demographic status when possible.

(2) On July 20, samples were also collected from other tide levels on the beach. The tide levels sampled included $+3,+2,+1$ and $-1 \mathrm{~m}$, in addition to the $0 \mathrm{~m}$ collection described above. An attempt was made to sample at $-3 \mathrm{~m}$ from shipboard, but was unsuccessful due to the rocky nature of the substrate. The samples collected at this time were part of a larger effort to describe changes in the meiofaunal community from high in the intertidal to depths of $50 \mathrm{~m}$ in Auke Bay (Fleeger et al. unpubl.). All samples were processed as described above.

In addition, semi-quantitative meiofaunal collections were made from nearby seagrass beds and algal habitats to determine the nature of the harpacticoid community inhabiting that area. In these areas, the epiphytic harpacticoid communities were sampled by taking clippings from the vegetation, which were fixed and stained as for benthic samples.

It is now well documented that harpacticoid copepods are common in near-bottom waters overlying many sediments (Palmer 1988a), entering the water column by either passive or active means. The result could be differential prey availability. Eight replicate emergence traps and 8 settlement traps were set in place at the $0 \mathrm{~m}$ transect on July 21, 1989, to determine if certain species are more inclined than others to leave the sediments upon immersion. Emergence traps were of the dimensions described by Walters \& Bell (1986). The traps were not, however, placed flush with the sediment but rather some $1 \mathrm{~cm}$ above the sediment surface. This allows free movement of water at the sediment-water interface and enables organisms which did not emerge from the sediment immediately beneath the trap to enter it. The inverted funnel design requires organisms to reach a height of some 6 to $7 \mathrm{~cm}$ above the sediment surface to enter the trap. The emergence traps were placed at random locations along the transect at low tide and allowed to remain in place for $24 \mathrm{~h}$. On collection, the contents were fixed with $10 \%$ formalin, stained with Rose Bengal. Samples were then analyzed in a manner similar to sediment meiofaunal samples.

Settlement traps were similar to those of Fegley (1988), which sample animals settling to the bottom. They consisted of glass test tubes $(1.2 \mathrm{~cm}$ i.d. $\times 12.2 \mathrm{~cm}$ long) buried flush with the sediment and filled with filtered seawater. The surrounding sediment was replaced to a depth of $5 \mathrm{~cm}$ by azoic sediment to avoid the sloughing of animals into the trap. The dimensions of the traps were chosen to minimize hydrodynamic effects that could sweep trapped animals out of the tube. This is a significant consideration in the design of settlement traps, particularly with animals such as harpacticoid copepods that are strongly influenced by the hydrodynamic regime. The traps utilized had an aspect ratio (ratio of trap length to opening diameter) of 10. Lau (1979) demonstrated that cylindrical traps with this aspect ratio would retain trapped particles up to trap Reynolds numbers of 20000 . Fegley calculated that for traps of these dimensions, a current speed of $140 \mathrm{~cm} \mathrm{~s}^{-1}$ at the trap opening was required for resuspension of trapped particles. These traps were placed in position at random locations on the transect at low tide and were left in position for $24 \mathrm{~h}$. They were then collected, and the contents fixed, stained and analyzed as described above.

Sigma-Scan ${ }^{\mathrm{m}}$ image analysis software was employed to determine average lengths of the most common species of harpacticoid copepods. A stereomicroscope with a camera lucida and a digitizing pad were employed in the measurement of harpacticoids. All statistical analyses were performed with Statistical Analysis System (SAS 1990) software.

\section{RESULTS}

The diet of juvenile Platichthys stellatus less than $30 \mathrm{~mm}$ standard length is dominated by harpacticoid copepods, which comprise $89 \%$ of its prey (McGregor 1991). P. stellatus settle out of the water column in late June or early July and juveniles are present on the beach throughout the summer, although in late summer or early fall they have reached sizes (>35 mm SL) at which meiofauna become insignificant to their diet.

This site also supports very high densities of harpacticoid copepods (McGregor 1991). Mean densities of adults in May 1987 were $2.6 \times 10^{6} \mathrm{~m}^{-2}$, among the highest harpacticoid densities observed worldwide. The sediment assemblage was dominated by 3 species, Halectinosoma sp., Amphiascoides dimorphus Lang and Microarthridion littorale, although some 10 to 12 other species were present in lesser numbers. Harpacticoid densities underwent dramatic variations seasonally, with extremely high densities in the late spring decreasing through the summer and fall. This work focuses on the summer months when flatfish predators were abundant.

Summer collections reveal that Halectinosoma sp. was the most abundant species, followed by Amphiascoides dimorphus. Microarthridion littorale was the third most abundant species, not approaching the densities of the 2 more abundant species (Table 1). Typically 30 to $40 \%$ of adult $M$. littorale were male, a higher proportion than that shown by the 2 more abundant species. $M$. littorale also showed the highest ratio of copepodites to adults during the summer, with cope- 
Table 1. Halectinosoma sp., Amphiascoides dimorphus, Mircoarthridion littorale. Sediment density (no. per $\left.10 \mathrm{~cm}^{2}\right) \pm \mathrm{SE}$, percentage of aduits which were male, and ratio of copepodites to adults for the 3 most abundant species of harpacticoid copepods during summer 1987 (includes 1 sample from 1988). All collections consisted of 4 replicate cores on the $0 \mathrm{~m}$ transect with the exception of the June 16 and August 23 collections, which consisted of 3 replicate samples

\begin{tabular}{|c|c|c|c|c|}
\hline Date & & Halectinosoma sp. & A. dimorphus & M. Iittorale \\
\hline Jun 16,1987 & $\begin{array}{l}\text { Density } \\
\% \text { male } \\
\text { Copepodite/adult }\end{array}$ & $\begin{array}{c}637.4 \pm 45.5 \\
42.7 \\
0.32\end{array}$ & $\begin{array}{c}97.7 \pm 15.7 \\
28.2 \\
0.14\end{array}$ & $\begin{array}{c}37.7 \pm 7.0 \\
38.3 \\
1.85\end{array}$ \\
\hline Jul 10, 1987 & $\begin{array}{l}\text { Density } \\
\% \text { male } \\
\text { Copepodite/adult }\end{array}$ & $\begin{array}{c}196.9 \pm 39.1 \\
23.0 \\
0.01\end{array}$ & $\begin{array}{c}75.8 \pm 22.4 \\
18.0 \\
0.01\end{array}$ & $\begin{array}{c}60.8 \pm 15.5 \\
40.3 \\
0.83\end{array}$ \\
\hline Jul 27, 1987 & $\begin{array}{l}\text { Density } \\
\% \text { male } \\
\text { Copepodite/adult }\end{array}$ & $\begin{array}{c}394.2 \pm 55.9 \\
15.4 \\
0.01\end{array}$ & $\begin{array}{c}147.4 \pm 24.0 \\
14.1 \\
0.00\end{array}$ & $\begin{array}{l}81.5 \pm 9.0 \\
28.9 \\
0.70\end{array}$ \\
\hline Aug 10, 1987 & $\begin{array}{l}\text { Density } \\
\% \text { male } \\
\text { Copepodite/adult }\end{array}$ & $\begin{array}{c}427.2 \pm 173.6 \\
7.3 \\
0.02\end{array}$ & $\begin{array}{c}140.3 \pm 35.2 \\
14.4 \\
0.01\end{array}$ & $\begin{array}{l}38.2 \pm 14.8 \\
38.3 \\
0.69\end{array}$ \\
\hline Aug 23, 1987 & $\begin{array}{l}\text { Density } \\
\% \text { male } \\
\text { Copepodite/adult }\end{array}$ & $\begin{array}{c}219.8 \pm 70.6 \\
8.9 \\
0.01\end{array}$ & $\begin{array}{c}103.0 \pm 5.9 \\
9.2 \\
0.01\end{array}$ & $\begin{array}{l}59.7 \pm 28.9 \\
29.5 \\
0.47\end{array}$ \\
\hline Sep 8, 1987 & $\begin{array}{l}\text { Density } \\
\% \text { male } \\
\text { Copepodite/adult }\end{array}$ & $\begin{array}{c}179.0 \pm 53.4 \\
6.1 \\
0.06\end{array}$ & $\begin{array}{c}42.9 \pm 7.2 \\
11.0 \\
0.00\end{array}$ & $\begin{array}{l}29.7 \pm 6.6 \\
\quad 46.0 \\
0.27\end{array}$ \\
\hline Jul 1, 1988 & $\begin{array}{l}\text { Density } \\
\% \text { male } \\
\text { Copepodite/adult }\end{array}$ & $\begin{array}{c}446.0 \pm 132.5 \\
16.1 \\
0.02\end{array}$ & $\begin{array}{c}156.4 \pm 56.0 \\
11.0 \\
0.00\end{array}$ & $\begin{array}{l}30.6 \pm 12.9 \\
0.27 \\
0.27\end{array}$ \\
\hline
\end{tabular}

podite densities approaching or exceeding $50 \%$ of adult densities in most months. Copepodites of other species were relatively rare in summer after a peak in late spring.

Stomach content analyses of 120 Platichthys stellatus less than $25 \mathrm{~mm}$ standard length reveal that Microarthridion littorale dominates their diet (Table 2). In fact, $M$. littorale comprised greater than $76 \%$ of the copepods in the stomach contents. In addition, a sexual bias was evident. Male $M$. Iittorale were taken as prey in greater numbers than females or copepodites. On average, $73 \%$ of ingested $M$. littorale were male. A comparison of starry flounder stomach contents to sediment meiofauna samples on 2 representative sampling dates indicates that $M$. littorale made up a much higher proportion of the harpacticoids ingested by juvenile $P$. stellatus than in the sediment assemblage (Fig. 1). Furthermore, male $M$. littorale were propor-

Table 2. Platichthys stellatus. Gut contents of juveniles (<25 mm) collected on 10 sampling dates in 1987-1989, with number of fish examined (n), mean number of harpacticoid copepods per fish, percentage of harpacticoids which were Microarthridion littorale, percentage of $M$. Iittorale which were male, and ratio of $M$. littorale copepodites to adults

\begin{tabular}{|lrcrrr|}
\hline Date & n. & $\begin{array}{c}\text { Mean no. } \\
\text { of harpacticoids }\end{array}$ & $\begin{array}{c}\% \\
\text { M. littorale }\end{array}$ & $\begin{array}{c}\text { \% } \\
\text { male }\end{array}$ & $\begin{array}{c}\text { Copepodite/adult } \\
\text { ratio }\end{array}$ \\
\hline Jul 27, 1987 & 16 & 44.8 & 84.7 & 74.0 & 0.37 \\
Aug 11, 1987 & 8 & 8.4 & 62.7 & 71.0 & 0.35 \\
Aug 23, 1987 & 5 & 4.0 & 50.0 & 77.8 & 0.11 \\
Sep 8, 1987 & 2 & 4.0 & 37.5 & 66.7 & 0.00 \\
Jun 14, 1988 & 2 & 3.5 & 71.4 & 60.0 & 0.00 \\
Jul 1, 1988 & 19 & 15.63 & 79.5 & 66.9 & 0.33 \\
Jul 7, 1989 & 15 & 19.6 & 87.2 & 83.2 & 0.15 \\
Jul 17, 1989 & 19 & 28.2 & 71.4 & 73.3 & 0.41 \\
Jul 19, 1989 & 20 & 14.0 & 74.3 & 69.1 & 0.33 \\
Jul 21, 1989 & 14 & 26.2 & & & 0.28 \\
\hline
\end{tabular}


a

Sediment - July 27,1987

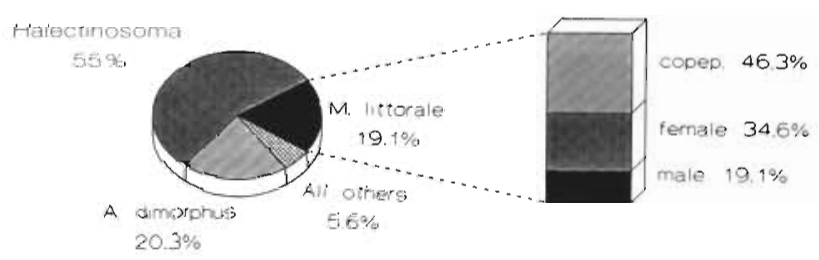

b

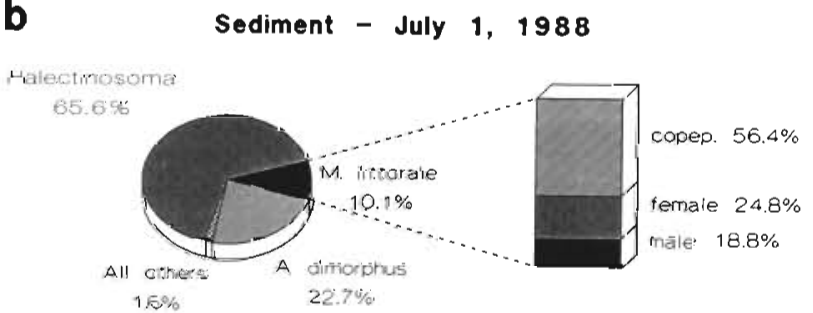

C

Ingested - July 27,1987

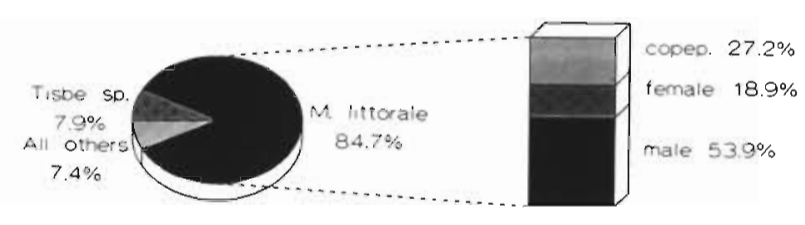

d

Ingested - July 1, 1988

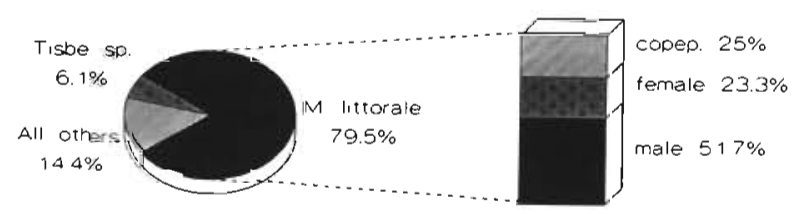

Fig. 1. Comparison of sediment harpacticoid assemblage with that found in stomachs of juvenile Platichthys stellatus on 2 sampling dates. (a) Sediment assemblage on July 27, 1987. Species composition is represented in pie diagram, with demographic breakdown of Microarthridion littorale depicted in bar graph. (b) Sediment assemblage on July 1, 1988. (c) Harpactioids in guts of $P$. stellatus collected on July 27, 1988. (d) Harpacticoids in P. stellatus guts on July 1, 1988

tionately much more abundant in $P$. stellatus gut contents than in sediment samples (Fig. 1). The most abundant sediment harpacticoid species, Halectinosoma sp. and Amphiascoides dimorphus, were rare in $P$. stellatus stomachs. The second most abundant genus of harpacticoid taken as prey was Tisbe, a genus that has been noted for its epibenthic lifestyle (Walters \& Bell 1986).

Average lengths of harpacticoid species at the site were determined by image analysis (Table 3). While Microarthridion littorale are significantly larger than the other abundant sediment-dwelling species, males are not significantly larger than females. Furthermore, males in the stomach contents of Platichthys stellatus are not significantly larger than male or female $M$. littorale in the sediment. In fact, preliminary evidence

Table 3. Means and standard errors for lengths $(\mathrm{mm})$ of adult male and female Microarthridion littorale, $M$. littorale copepodites, and adult females of Amphiascoides dimorphus and Halectinosoma sp. Male A. dimorphus and Halectinosoma are rare and were not included in the analysis. Groups found to differ significantly $(\mathrm{p}<0.05)$ in length by Duncan's multiple range test are indicated by different letters

\begin{tabular}{|lccc|}
\hline & Mean & SE & \\
\cline { 3 - 4 } M. littorale o & 0.653 & 0.0159 & $\mathrm{~A}$ \\
M. littorale 9 & 0.631 & 0.0167 & $\mathrm{~A}$ \\
A. dimorphus $\%$ & 0.552 & 0.0128 & $\mathrm{~B}$ \\
Halectinosoma sp. $\$$ & 0.569 & 0.0077 & $\mathrm{~B}$ \\
M. littorale cop. & 0.387 & 0.0263 & $\mathrm{C}$ \\
\hline
\end{tabular}

indicates that ingested $M$. littorale (of all demographic groups) may be smaller than those in the sediment.

Core samples taken in a perpendicular transect on the beach from the +3 to the $-1 \mathrm{~m}$ tide level do not reveal a location where Microarthridion littorale is more abundant than at the area of fish collection. Densities of $M$. littorale were highest at the $-1 \mathrm{~m}$ and $0 \mathrm{~m}$ transects, with lower densities at $+1 \mathrm{~m}$ (Fig. 2). Transects at +2 and $+3 \mathrm{~m}$ revealed negligible densities of $M$. littorale.

Semi-quantitative samples taken from fronds of Fucus were dominated by Harpacticus sp., a preferred prey of juvenile salmonids (Sibert 1979) while Microarthridion littorale was rare in these samples. Harpacticoids were also present in samples taken from clipped leaves of Zostera marina. These samples contained species found in sediment samples, notably Amphiascoides dimorphus, in addition to Harpacticus sp. $M$. littorale was also rare in these samples.

A series of vertically sectioned cores taken in July 1989 indicated that densities of all common species of harpacticoids decreased rapidly with depth (Fig. 3). Vertical distribution of adult Microarthridion littorale was compared to that of other adult harpacticoids by 2-sample Kolmogorov-Smirnov tests for $0 \mathrm{~m}$ collections on July 7 and July 20, 1987, and $-1 \mathrm{~m}$ collections on July 20, 1987 . The July 20 collection at $0 \mathrm{~m}$ indicated a significantly more surficial distribution for $M$. littorale than for other adult harpacticoids $\left(D^{*}{ }_{05}=0.162, D_{\max }=\right.$ 0.373 ). However, $M$. littorale made up only $16 \%$ of the harpacticoid assemblage in the surface sediments in 
a

-1 meter
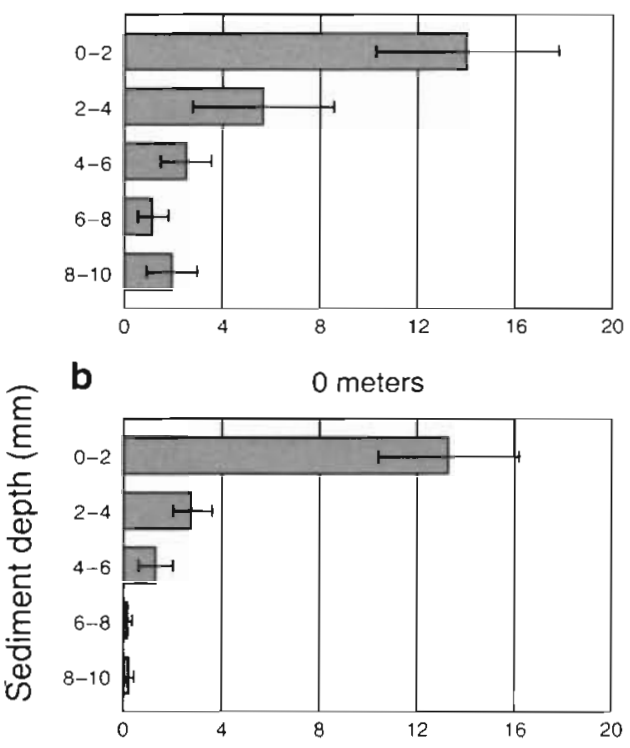

C +1 meter

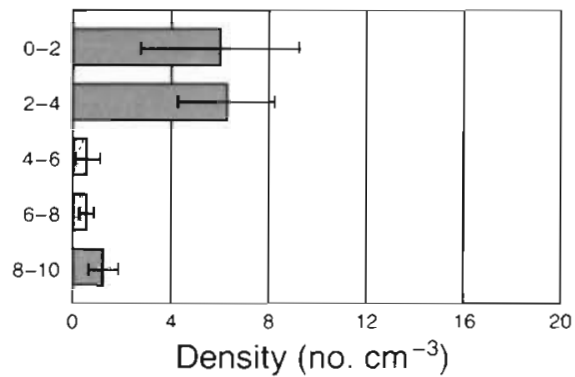

Fig. 2. Microarthridion littorale. Density and vertical distribution on July 19,1989 at (a) -1 m tide level, (b) $0 \mathrm{~m}$ tide level, and (c) $+1 \mathrm{~m}$ tide level. Means and $1 \mathrm{SE}$ are indicated
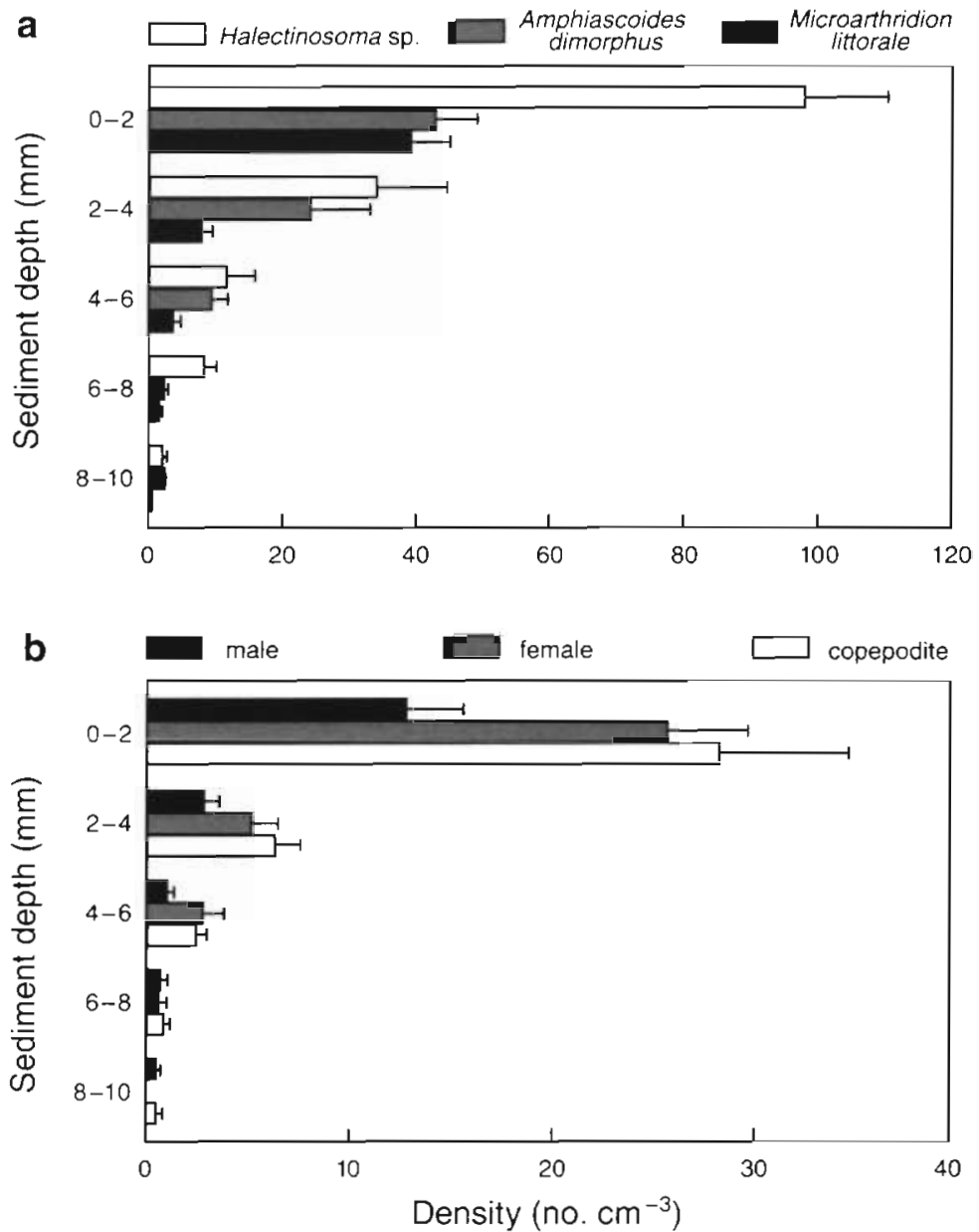

Fig. 3. Densities and vertical distributions of harpacticoid copepods on 0 in transect on July 7, 1989. Mean and 1 SE are indicated. (a) Vertical distribution of 3 most abundant species. (b) Vertical distribution of demographic groups of Microarthridion littorale this collection. Test results for the other 2 collections indicate that $M$. littorale distributions were not significantly different from that of other adult harpacticoids. Similarly, densities of all demographic groups (males, female and copepodites) of $M$. littorale were highest at the surface and decreased rapidly with depth (Fig. 3B). Two-sample Kolmogorov-Sminov tests were utilized to compare distributions of adult male and female $M$. littorale. In no case were the distributions found to be significantly different. Similarly sectioned cores at the 1, 2 and $3 \mathrm{~m}$ tidal levels also showed no concentration of $M$. littorale in surface sediments. Vertical distribution of $M$. littorale was similar over all tide levels at which they were collected (Fig. 2).

Two sampling approaches, emergence traps and settlement traps, were employed to measure the tendencies of harpacticoids to leave the sediment during immersion (Fig. 4a, b). Harpacticoids made up some $70 \%$ of the copepods in emergence trap collections, with the remaining $30 \%$ approximately equally split between cyclopoids and calanoids. The most abundant harpacticoids in emergence trap collections were of the genus Tisbe, a genus frequently found in hyperbenthic collections (Walters \& Bell 1986). Approximately $60 \%$ of the copepods collected in settlement traps were harpacticoids, with most of the remainder being cyclopoids. Calanoids were rare in settlement trap collections. Copepods must swim some $7 \mathrm{~cm}$ above the sediment surface to enter emergence traps. Settlement traps, on the other hand, are effective collectors of near-bottom fauna (Fegley 1988) and settlement trap harpacticoid assemblages resembled that ingested by Platichthys stellatus with Microarthridion littorale making up some $40 \%$ of the harpacticoids collected in these traps $176 \%$ in stomach contents)

Table 4 presents similarity values of the harpacticoid assemblages collected in the entire sediment cores, the 


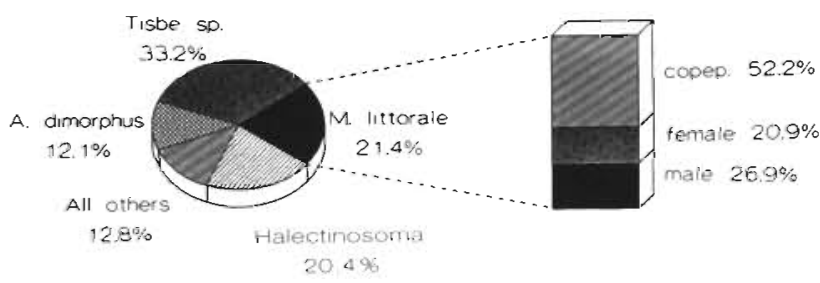

b

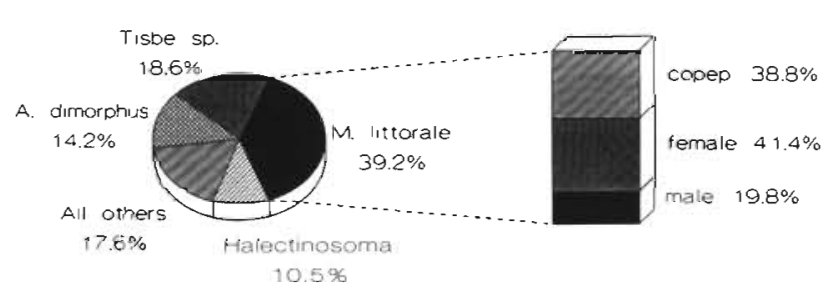

Fig. 4. Harpacticoid copepods collected in (a) emergence traps and (b) settlement traps on July 21, 1989. Pie diagram represents species composition; bar graph depicts the demographic composition of Microarthridion littorale

upper $2 \mathrm{~mm}$ of the sediment, settlement traps, emergence traps and those found in guts of Platichthys stellatus. At the species level, sediment collections (both the entire $1 \mathrm{~cm}$ core and the upper $2 \mathrm{~mm}$ ) and emergence traps showed $<40 \%$ similarity to $P$. stellatus prey. The greatest similarity to flounder diets $(66.2 \%)$ occurs in the settlement trap collections, implying that the visually feeding $P$. stellatus are ingesting harpacticoids in the near-bottom waters.

Table 4. Percent similarities of harpacticoid copepod assemblages represented in different collections. FLATFISH PREY = copepods identified in Platichthys stellatus gut contents, UPPER SED = copepods in upper $2 \mathrm{~mm}$ of sediment cores, ENTIRE SED = copepods in entire upper $1 \mathrm{~cm}$ of sediment cores, EMERGE = copepods collected in emergence traps, and SETTLE = copepods collected in settlement traps

\begin{tabular}{|c|c|c|c|c|c|}
\hline & $\begin{array}{c}\text { FLATFISH } \\
\text { PREY }\end{array}$ & $\begin{array}{l}\text { UPPER } \\
\text { SED }\end{array}$ & $\begin{array}{c}\text { ENTIRE } \\
\text { SED }\end{array}$ & EMERGE & SETTLE \\
\hline $\begin{array}{l}\text { FLATFISH } \\
\text { PREY }\end{array}$ & - & 25.4 & 31.3 & 35.1 & 66.2 \\
\hline $\begin{array}{l}\text { UPPER } \\
\text { SED }\end{array}$ & & - & 92.1 & 56.9 & 55.2 \\
\hline $\begin{array}{l}\text { ENTIRE } \\
\text { SED }\end{array}$ & & & - & 59.4 & 61.0 \\
\hline EMERGE & & & & - & 62.6 \\
\hline SETTLE & & & & & - \\
\hline
\end{tabular}

\section{DISCUSSION}

Juvenile Platichthys stellatus prey almost exclusively on harpacticoid copepods and their diet is dominated by male Microarthridion littorale. This harpacticoid is not dominant in the sediments, nor can selection by explained by prey size differences. Harpacticoids in the gut contents of juvenile $P$. stellatus do not closely resemble those in the sediments or in emergence traps, but do closely resemble those in settlement traps (Table 4). Thus it seems likely that $P$. stellatus feeds heavily on harpacticoids from near-bottom water (Table 4).

Selective feeding in many fish species has been explained by prey-size selection. Such selection can be for larger (Brooks \& Dodson 1965, Werner \& Hall 1974) or smaller (Schmitt \& Holbrook 1984, Bence \& Murdoch 1986) prey types. Microarthridion littorale is significantly larger than other abundant sediment harpacticoids. Male $M$. littorale, however, do not differ significantly in length from females. In fact, the male is more slender and likely represents a smaller energetic gain. It does not appear that prey size provides a complete explanation for the feeding selection demonstrated by Platichthys stellatus.

Alternatively, Platichthys stellatus may feed at a site other than the site of fish collection. This a common criticism of studies attempting to compare fish food habits to that available in the environment (Gee 1987). Flatfish have been shown to use tidal migration as a feeding strategy (Wolff et al. 1981), moving onto tidal flats at high tide and returning to adjacent channels with the falling tide. Feller et al. (1990), working with the sciaenid Leiostomus xanthurus, found that the species composition of the harpacticoids in the diet can be used to identify the location in which the fish feed.

I could find no area in which Microarthridion littorale was more abundant than at the site of fish collection. Furthermore, I found no tide level where the $M$. littorale population was dominated by males (unpubl. data). M. littorale were not present at extensively sampled subtidal stations (18 to $25 \mathrm{~m}$ ) near my study site from 1985 to 1989 (Fleeger \& Shirley 1990). My inability to sample at -2 and $-3 \mathrm{~m}$ depths is troublesome, but not overly so. All fish collections were made at low tide. Tidal ranges in the bay are from 5 to $7 \mathrm{~m}$, resulting in an extremely strong tidal current. It is highly unlikely that the fish fed at lower tidal levels than that at which they were collected, since the juvenile flatfish would have had to work their way up to the point of collection against a very strong outflowing tide. In addition, there is no indication that adjacent algal and seagrass beds are heavily utilized as feeding areas. The selectivity of Platichthys stellatus cannot be explained solely as resulting from feeding in another locale. 
A third potential explanation of the observed selection is that harpacticoids may differ in vertical distribution within the sediment, with the more surficial species more easily preyed upon than deeper interstitial or burrowing animals. This pattern has been observed by Gee (1987) who showed that an epibenthic harpacticoid was selectively preyed upon by juvenile flatfish. Furthermore, Fleeger (1979) observed consistently high mortality rates in Microarthridion littorale and hypothesized that its surficial nature might lead to greater susceptibility to predation. My study indicates that Microarthridion littorale does not differ significantly in vertical distribution from other abundant harpacticoids. It appears that differing vertical distributions cannot be invoked as an explanation for the selection of male $M$. littorale as prey.

A fourth factor that might explain selection relates to the behavior of harpacticoid copepods. For example, species (or sexes) that emerge from the sediments probably increase their susceptibility to predation (Palmer 1988b), particularly by visual predators preying on small prey organisms.

There has recently been increasing recognition of a hyperbenthic (or near-bottom) meiofaunal assemblage, containing elements of 2 origins: downwardmoving planktonic species and upward-moving benthic species (Sibert 1981, Fleeger et al. 1983). Walters \& Bell (1986) found that large numbers of harpacticoid copepods (19 of 36 species) migrated from the sediment into the water column in a Florida (USA) seagrass bed. Sibert (1981) analyzed pump samples collected $30 \mathrm{~cm}$ and $5 \mathrm{~cm}$ above the sediment surface in British Columbia. He found that the 'plankton' density was always greater at $5 \mathrm{~cm}$ than at $30 \mathrm{~cm}$, and that these samples were dominated by copepod nauplii and harpacticoid copepods. Sibert also pointed out the potential significance of the hyperbenthos as food for demersal predators, and discussed a sample of chum salmon fry collected at his study site. Salmon fry stomach contents revealed that approximately $60 \%$ of their prey were Microarthridion littorale, and, while $M$. littorale was among the more abundant harpacticoids. it does not constitute a majority of the available prey. It is possible that juvenile salmon may also exploit emergent $M$. littorale in the near-bottom waters. In addition, preliminary work on postlarval spot Leiostomus xanthurus Lacépède suggests a reliance on hyperbenthic prey before shifting to an infaunal meiofaunal assemblage (McCall unpubl.). Given that many juvenile fish feed in the near-bottom waters, more study is warranted on the dietary role played by the ubiquitous hyperbenthic meiofauna.

Settlement trap data indicates that Microarthridion littorale may indeed be more abundant in the nearbottom water than their sediment density would indi- cate. Demographic evidence, however, is contradictory. The hyperbenthic $M$. littorale assemblage does not appear to be dominated by males, as might be predicted from the feeding habits of juvenile Platichthys stellatus. While species-specific predation on harpacticoid copepods has been observed in a number of circumstances, sex-specific predation is less well-documented. Maly (1970), investigating predation on calanoid copepods of the genus Diaptomus, found differential predation on males and females due to an interaction between the hunting behavior of the predator and the size and activity of male and female copepods. He also found that the adult sex ratios of the prey could be altered by sex-biased predation. Hicks \& Marshall (1985) found that certain deep-sea carnivorous bivalves feed almost exclusively on male harpacticoids, and went on to speculate that this could play a role in biasing sex ratios in the deep sea toward females. They further suggested that bioluminescence may be a factor leading to this selection. In Alaska, behavioral differences between the harpacticoid sexes, particularly swimming behavior associated with copulation, may play a role in the sexual bias shown in flatfish feeding. As in most harpacticoids, male $M$. littorale engage in a precopulatory association with juvenile females (copepodites) in which the male grasps the copepodite with a specially adapted antennule. Hicks (1988) discusses the link between swimming behavior and precopulatory associations between mature males and late-stage female copepodites, and suggests that these associations must normally take place in the water column. Emergent behavior could lead to greater susceptibility to predation not only through increased availability, but also through greater visibility due to movement.

If, in fact, males and copepodites of Microarthridion littorale emerge from the sediments and are disproportionately abundant in the near-bottom waters while searching for partners, then males, which are significantly larger than copepodites, might well be more readily preyed upon by epibenthic predators such as Platichthys stellatus. The greater size of male $M$. littorale might also explain why they are taken in greater numbers than the cyclopoid copepods which are also abundant in the near-bottom water and have an approximate size range of 0.38 to $0.45 \mathrm{~mm}$. The observed feeding pattern of the juvenile fish thus might be the result of a combination of behaviors, the emergent behavior of the copepods and the feeding behavior of the fish.

Many researchers examining feeding in meiofaunal predators have been content to identify prey to major taxon (Sogard 1984, St. John et al. 1989). In this case, species-specific identification aided greatly in the identification of the source of copepods in the diet of 
juvenile Platichthys stellatus as different assemblages are found in the sediment, the hyperbenthos and on vegetation. A simple comparison illustrates that major taxon identifications can be misleading in other ways. Densities of the harpacticoid assemblage at the Auke Bay site compared to the number of juvenile flatfish collected in seine samples (an admittedly crude indicator of flatfish density) shows a sharp decline in the density of adult harpacticoids coincident with the arrival of juvenile flatfish (Fig. 5a). Harpacticoid numbers remain low during the summer and fall when the flatfish are present on the beach. It would be tempting to conclude that flatfish predation exerts a controlling influence on harpacticoid abundance, and in fact relationships of this type have been cited as evidence of predator control of prey populations (Heip \& Smol 1975). However, if flatfish numbers are compared to
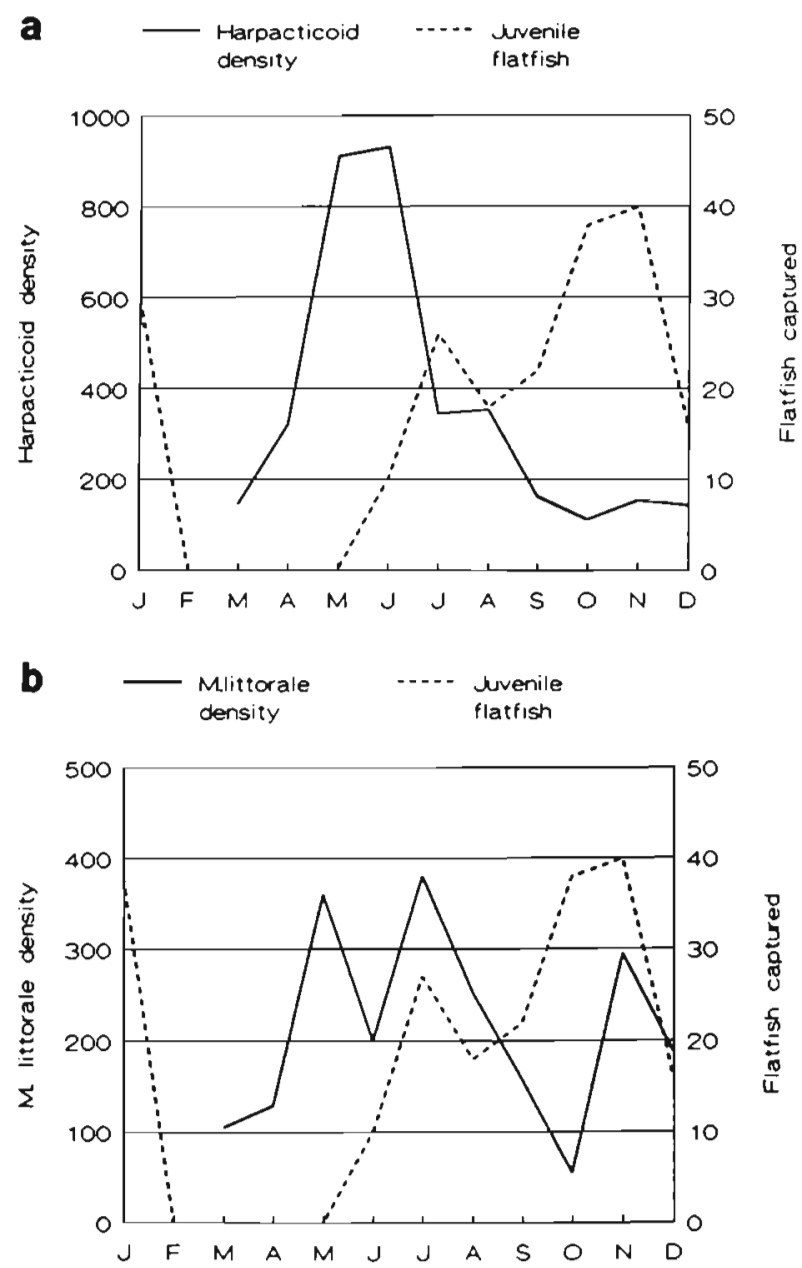

Fig. 5. Comparison of (a) total adult harpacticoid densities at Auke Bay site to number of juvenile flatfish captured over the period from March 1987 to Jan 1988 and (b) densities of adult Microarthidion littorale to flatfish captured over the same period the density of their primary prey, Microarthridion littorale (Fig. 5b), the apparent relationship between predator abundance and prey density becomes much more ambiguous. $M$. littorale densities, while showing a decline coincident with the arrival of the flatfish, increase shortly thereafter. This illustrates well the dangers inherent in correlational approaches to predation impact assessments, and the value of species-level identification of prey items. While there are certainly instances where the time-intensive process of species identification of harpacticoid prey may not yield valuable information (Coull 1990), there are cases where species identification and even information on demographic status can be of great interest. These results are also in agreement with the finding of Hicks (1984) and Gee (1987) who concluded that fish predation did not limit harpacticoid densities.

Acknowledgments. I especially thank John Fleeger for his guidance during this research and for his editorial comments on this manuscript. I also acknowledge the valuable comments of 3 anonymous reviewers. I am particularly grateful to Sue McGregor for allowing me to examine her samples. Tom Shirley's advice and assistance during my stay in Juneau were invaluable, as was the help of Lynnette McNutt. Shane Carr, Jeff Gruner and Toi Nguyen provided assistance in the processing of samples. Portions of this work were supported financially by a grant-in-aid from Sigma $X i$ and by the APPRISE program, a collaborative research effort between the Juneau Center for Fisheries and Ocean Sciences and the Institute of Marine Science (under the School of Fisheries and Ocean Sciences, University of Alaska Fairbanks), and the Oceanic Institute (Waimanalo, Hawaii). The APPRISE program is supported by Contract No. NA-85-ABH-0022 from the U.S. Department of Commerce, National Oceanic and Atmospheric Administration.

\section{LITERATURE CITED}

Bence, J. R., Murdoch, W. W. (1986). Prey size selection by the mosquitofish: relation to optimal diet theory. Ecology 67 : $324-336$

Brooks, J. L., Dodson, S. I. (1965). Predation, body size and composition of plankton. Science 150: 28-35

Coull, B. C. (1988). Ecology of the marine meiofauna. In: Higgins, R. P., Thiel, H. (eds.) Introduction to the study of meiofauna. Smithsonian Institution Press, Washington

Coull, B. C. (1990). Are members of the meiofauna food for higher trophic levels? Trans. Am. Microsc. Soc. 109: 233-246

Fegley, S. R. (1988). A comparison of meiofaunal settlement on the sediment surface and recolonization of defaunated sandy sediment. J. exp. mar. Biol. Ecol. 123: 97-114

Feller, R. J., Coull, B. C., Hentschel, B. T. (1990). Meiobenthic copepods: tracers of where juvenile Leiostomus xanthurus (Pisces) feed? Can. J. Fish. Aquat. Sci. 47: 1913-1919

Fleeger, J. W. (1979). Population dynamics of three estuarine meiobenthic harpacticoids (Copepoda) in South Carolina. Mar. Biol. 52: 147-156 
Fleeger, J. W., Shirley, T. C., Ziemann, D. A. (1989). Meiofaunal responses to sedimentation from an Alaskan spring bloom. I. Major taxa. Mar. Ecol. Prog. Ser. 57: $137-145$

Fleeger, J. W., Shirley, T. C. (1990). Pelagic-benthic coupling: meiofauna dynamics and sedimentation related to spring phytoplankton blooms in Auke Bay, Alaska, 1985-89. In: Ziemann, D., Fulton-Bennett, K. W. (eds.) APPRISE: interannual variability and fisheries recruitment. The Oceanic Institute, Honolulu, p. 357-384

Fleeger, J. W., Sikora, W. B., Sikora, J. P. (1983). Spatial and long-term variation of meiobenthic-hyperbenthic copepods in Lake Ponchartrain, Louisiana. Estuar, coast. Shelf Sci. 16: 442-453

Fuller, C. M., Butman, C. A. (1988). A simple technique for fine-scale, vertical sectioning of fresh sediment cores. J. sedim. Petrol. 58: 763-768

Gee, J. M. (1987). Impact of epibenthic predation on estuarine intertidal harpacticoid copepod populations. Mar. Biol. 96: $497-510$

Gee, J. M. (1989). An ecological economic review of meiofauna as food for fish. Zool. J. Linn. Soc. 96-243-261

Heip, C., Smol, N. (1975). On the importance of Protohydra leuckarti as a predator of meiobenthic populations. In: Persoone, G., Jaspers, E. (eds.) Proc. 10th Eur. Mar. Biol. Symp. Universa Press, Wetteren, p. 285-296

Hicks, G. R. F. (1984). Spatio-temporal dynamics of a meiobenthic copepod and the impact of predationdisturbance. J. exp. mar. Biol. Ecol. 81: 47-72

Hicks, G. R. F. (1988). Evolutionary implications of swimming behavior in meiobenthic copepods. Hydrobiologia 167/168: 497-504

Hicks, G. R. F., Marshall, B. A. (1985). Sex selective predation of deep-sea, meiobenthic copepods by pectinacean bivalves and its influence of copepod sex ratios. N.Z. Jl mar. Freshwat. Res. 19: 227-231

Hicks, G. R. F., Coull, B. C. (1983). The ecology of marine meiobenthic harpacticoid copepods. Oceanogr, mar. biol. A. Rev. 21: 67-175

Lau, Y. L. (1979). Laboratory study of cylindrical sedimentation traps. J. Fish. Res. Bd Can. 36: 1288-1291

Maly, E. J. (1970). The influence of predation on the adult sex

This article was presented by S. P. Meyers, Baton Rouge, Louisiana, USA ratios of two copepod species. Limnol. Oceanogr. 15: $566-573$

McGregor, S. B. (1991). Seasonal and ontogenetic changes in meiofauna in the diets of postmetamorphic flatfish. M.S. thesis, Univ. of Alaska, Fairbanks

McIntyre, A. D. (1969). Ecology of marine meiobenthos. Biol. Rev. Cambridge Philos. Soc. 44: 245-290

Palmer, M. A. (1988). Dispersal of marine meiofauna: a review and conceptual model explaining passive transport and active emergence with implications for recruitment. Mar. Ecol. Prog. Ser. 48: 81-91

Palmer, M. A. (1988b). Epibenthic predators and marine meiofauna: separating predation, disturbance, and hydrodynamic effects. Ecology 69: 1251-1259

St. John, J., Jones, G. P., Sale, P. F. (1989). Distribution and abundance of soft-sediment meiofauna and a predatory goby in a coral reef lagoon. Coral Reefs: 8: 51-57

SAS Institute Inc. (1990). SAS user's guide: statistics, Version 5 Edition. SAS Institute Inc., Cary, NC

Schmitt, R. J., Holbrook, S. J. (1984). Gape-limitation, foraging tactics and prey size selectivity of two microcarnivorous species of fish. Oecologia 63: 6-12

Sibert, J. R. (1979). Detritus and juvenile salmon production in the Nanaimo estuary: II. Meiofauna available as food to juvenile chum salmon (Oncorhynchus keta). J. Fish. Res. Bd Can. 36: 497-503

Sibert, J. R. (1981). Intertidal hyperbenthic populations in the Nanaimo Estuary. Mar. Biol. 64: 259-265

Sogard, S. M. (1984). Utilization of meiofauna as a food source by a grassbed fish, the spotted dragonet Callionymus pauciradiatus. Mar. Ecol. Prog. Ser. 17: 183-191

Walters, K., Bell, S. S. (1986). Diel patterns of active vertical migration in seagrass meiofauna. Mar. Ecol. Prog. Ser. 34: $95-103$

Werner, E. E., Hall, D. J. (1974). Optimal foraging and the size selection of prey by the bluegill sunfish (Lepomis macrochirus). Ecology 55: 1042-1052

Wolff, W. J., Mandos, M. A. Sandee, A. J. J. (1981). Tidal migration of plaice and flounders as a feeding strategy In: Jones, N. V., Wolff, W. J. (eds.) Feeding and survival strategies of estuarine organisms. Plenum Press, New York, p. 159-171

Manuscript first received: February 2, 1992

Revised version accepted: July 2, 1992 